\title{
Assessment of Post-Harvest Fish Losses at the Landıng Site and during Transportation at Tema Fishing Harbour, Ghana
}

\section{Assan D ${ }^{1}$, Akongyuure DN2*, Abarike ED² and Guangli Li1**}

${ }^{1}$ Key Laboratory of Marine Ecology and Aquaculture Environment of Zhanjiang, Key Laboratory of Aquaculture in South China Sea for Aquatic Economic Animal of Guangdong Higher Education Institutes, Fisheries College, Guangdong Ocean University, China

${ }^{2}$ Department of Fisheries and Aquatic Resources Management, University for Development Studies, Ghana

*Corresponding author: Daniel Nsoh Akongyuure, Department of Fisheries and Aquatic Resources Management, University for Development Studies, P.O.Box TL 1882, Tamale, Ghana, Tel: +233208712941; Email: akongyuure2012@gmail.com

**Corresponding author: Guangli Li, Key laboratory of Marine Ecology and Aquaculture Environment of Zhanjiang, Key laboratory of Aquaculture in South China Sea for Aquatic Economic Animal of Guangdong Higher Education Institutes. Fisheries College, Guangdong Ocean University, Zhanjiang 524088. China, Tel: +8613822586807; Email: guangli211@163.com

\section{Abstract}

The fisheries sector in Ghana plays a significant role in food security and nutrition for many people, especially the poor. Fisheries importantly contribute to the animal protein supplies to many countries in the world, both the developed and developing ones. In developing countries, fisheries play an important role in food security. Fish is vulnerable to postharvest deterioration. Damage by post-harvest can be in the form of fleshly damage or spoilage. Mishandling of fish leads to physical damage whereas deprived hygiene and environments expedite spoilage. High temperature, inappropriate processing, storage and supply of fish are some of the phases that enhance the vulnerability of fish to physical damage. The study was conducted at Tema fishing harbour, Ghana to identify the types of post-harvest fish loss (PHFL) that occur at the landing site and during transportation. Questionnaires were randomly administered to 50 fishers (fishermen and transporters). The study identified burrito, herrings, redfish, moonfish, mackerel, and tuna as the fishes mostly harvested. Herrings were noted to have the highest spoilage vulnerability and the least was tuna. Physical losses were most frequently experienced by the fishers due to the mishandling of fish. The study recorded $12,600 \mathrm{~kg}(\mathrm{GH} \not 14,224.50)$ (2621.79\$) of fish harvested during the study period of which 2,196 kg (GH $\$ 2,418.20)(445.77 \$)$ was lost. It was 


\section{International Journal of Oceanography \& Aquaculture}

recommended that fishermen carry along with them enough ice when going fishing. Proper handling measures must also be followed for the reduction of fish spoilage.

Keywords: Post-Harvest; Landing Site; Transportation; Loss; Fishes; Spoilage

Abbreviations: LIFDCs: Low-Income Food Deficient Countries; NEPAD: New Economic Partnership for African Development; CAADP: Comprehensive African Agricultural Development Program; SPSS: Statistical Package for Social Sciences; PHFL: Post-Harvest Fish Loss.

\section{Introduction}

Fisheries importantly contribute to the supply of animal protein to many countries worldly, both the developed and developing ones [1]. In developing countries, the role of the fisheries sector is key in food security and nutrition for many people, especially the poor. In low-income food deficient countries (LIFDCs), most consume about $22 \%$ of animal proteins in all [2]. It is a major source of protein to more than 200 million people (30\%) of the African populace [3].

The New Economic Partnership for African Development (NEPAD) in association with the Comprehensive African Agricultural Development Program (CAADP) considers capture fisheries as a contributor to agricultural development in Africa [3]. The contribution of capture fisheries to food security, poverty reduction, and economic development is classified to be important in the African continent [2]. Capture fisheries similarly face a contest of broadening breach amongst an growing demand and a diminishing supply which has been accredited to inadequate post-harvest loss control among other factors $[2,4]$.

Fish is vulnerable to post-harvest damage. Postharvest damage can be in the form of fleshly impairment or spoilage. Rough handling of fish leads to physical damage while poor hygiene and sanitation environments expedite spoilage [4]. High temperature, inappropriate processing, storage and supply of fish are some of the factors that make fish prone to physical damage [5].

Fleshly impairment and spoilage result in the reduction of the market price which is associated with monetary losses or extremely the fish are thrown away. The level of post-harvest fish losses is influenced by several factors. The time interval from when the fish is harvested until it reaches the final consumer, which is determined by distance from the source, and the means of transport; affect the stages of post-harvest loss. Postharvest fish losses are also determined by physical features such as the size of the fish which depends on species and form of preservation. Additional aspects impelling loss are fish selling price; regularity of loading and unloading; high temperature and fishing gears used $[5,6]$.

Fish is an extremely fragile product and liable to spoilage immediately harvest [5]. Fish can get spoilt prior to inappropriate fish processing and preservation methods and ultimately rendering to financial loss [7]. Such losses are defined as post-harvest fish losses. Along the value chain line post-harvest fish losses do occur in diverse ways [2].

Raw fish spoilage contributes to $25 \%$ of food products that are lost to microbial activities yearly. Microbes can be found around the outer body covering and inner surfaces such as skin, gills and GI tracts of fresh fish. Fish's poikilothermic nature makes it prone to a wide range of bacteria to grow $[8,9]$.

The provision of adequate and affordable food (fish) for all is the fundamental basis for food security. Although there is remarkable progress made in increasing fishing worldwide, approximately half of the populations in developing countries do not have access to adequate food (fish) supplies, thus the food security problem is worsening $[1,2]$.

There are many reasons for inadequate fish supply but the most important of them is post-harvest fish losses, which occur throughout the supply chain, right from harvesting to marketing. The Tema fishing harbour supplies fish to most parts of Ghana but then, in one way or the other, it is insufficient partly due to post-harvest losses. This research was undertaken to investigate the various types of post-harvest fish loss that occurs from the landing site through to the transportation destination (Ashaiman market). This study also aimed at identifying some of the fish species that are mostly lost at the landing site and during transportation as well as the monetary value of the fish loss at the landing site and during 


\section{International Journal of Oceanography \& Aquaculture}

transportation during the study period, in other to create the awareness for immediate attention from stakeholders.

\section{Materials and Methods}

\section{Study Area}

The Tema harbour is situated in the south-eastern part of Ghana along the Gulf of Guinea. It lies along the Gulf of Guinea and is 18 miles away from Accra, the capital of the country. The harbour has a water-enclosed area of 1.7 million square meters and covers a total land of 3.9 million square meters. It lies on 410 acres (166 hectares) of the sea. The harbour has $5 \mathrm{~km}$ of breakwaters, 12 deep-water berths, 1 oil-tanker berth, one dockyard, a warehouse and transit sheds. In the east of the lee breakwater is the fishing harbour with cold storage and marketing facilities that handle fish processing.

\section{Sampling and Data Collection Method}

Fifty (50) people (fishers), comprising the fishermen and those in charge of the transporting from the landing site to the Ashaiman market (transport destination) were chosen randomly and the questionnaire was administered. Direct observations were made to identify how physical and quality losses occur.

\section{Data Analysis}

Data obtained from the questionnaire were coded and entered into a database system, using a Statistical Package for Social Sciences (SPSS) version 20. The quantity harvested and sold, and monetary value of fish harvested was presented by adding the first and last digit of every range (crates and amount, respectively) and dividing by two (2) to find the average and multiplying by the number of people who fall under a particular range and then summing all up to get the total.

The monetary value of fish lost through PHFL was determined using the following relation:

$$
\text { Amount lost }=\frac{Z}{X} \times \mathbf{Y}
$$

Where $\mathbf{X}$ represents the amount of fish harvested in $\mathrm{kg}, \mathbf{Y}$ is the monetary value for the fish harvested, $\mathbf{Z}$ is the amount (kg) of fish lost due to PHFL.

Differences in losses from the landing site and during transportation were added to determine the highest and lowest, as well as the types of PHFLs experience both at the landing site and during transportation.

\section{Results}

\section{Types of Post-Harvest Fish Loss}

The types of post-harvest fish loss experienced at the landing site of the Tema fishing harbour and during fish transportation from the landing site are physical, quality, economic and market force loss (Figure 1). It was identified that both physical and quality losses were caused by poor handling practices, fish not properly preserved on board (icing), less quality packaging materials and unsuitable transport facilities.

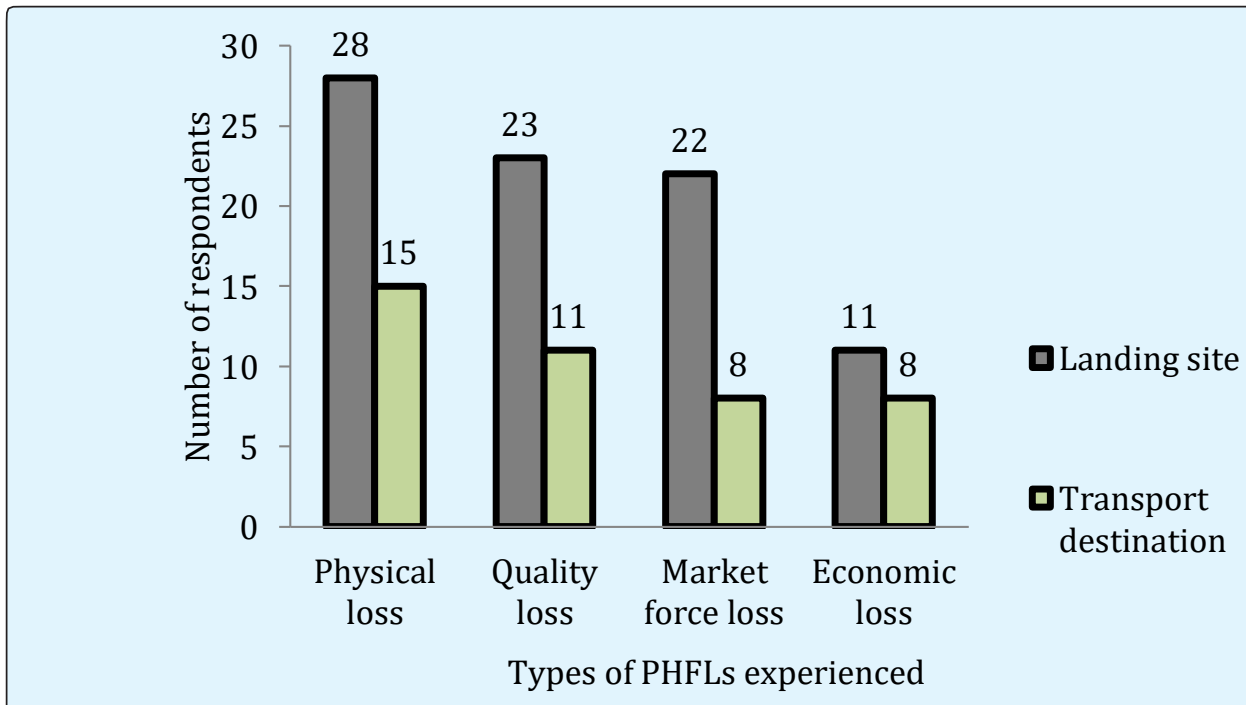

Figure 1: Types of PHFLs at the landing site and Ashaiman market (transport destination). 
Among these four types of PHFLs experienced, out of the fifty respondents (fishers), the one most experienced was the physical (43 and the least was economic loss (19). At the landing site and Ashaiman market where the fresh fish are sold respectively, 28 and 15 fishers experienced the physical loss, 23 and 11 experienced quality loss, 22 and 8 experienced market force loss whiles 11 and 8 experienced economic loss (Figure 1).

\section{Fish Spoilage Vulnerable}

Burrito, herrings, moonfish, redfish, mackerel, and tuna were the most harvested fish species and herrings turned out to be the highly vulnerable fish species to spoilage with 22 respondents; whiles tuna, on the other hand, was the lowest with 31 respondents agreeing to it (Figure 2).

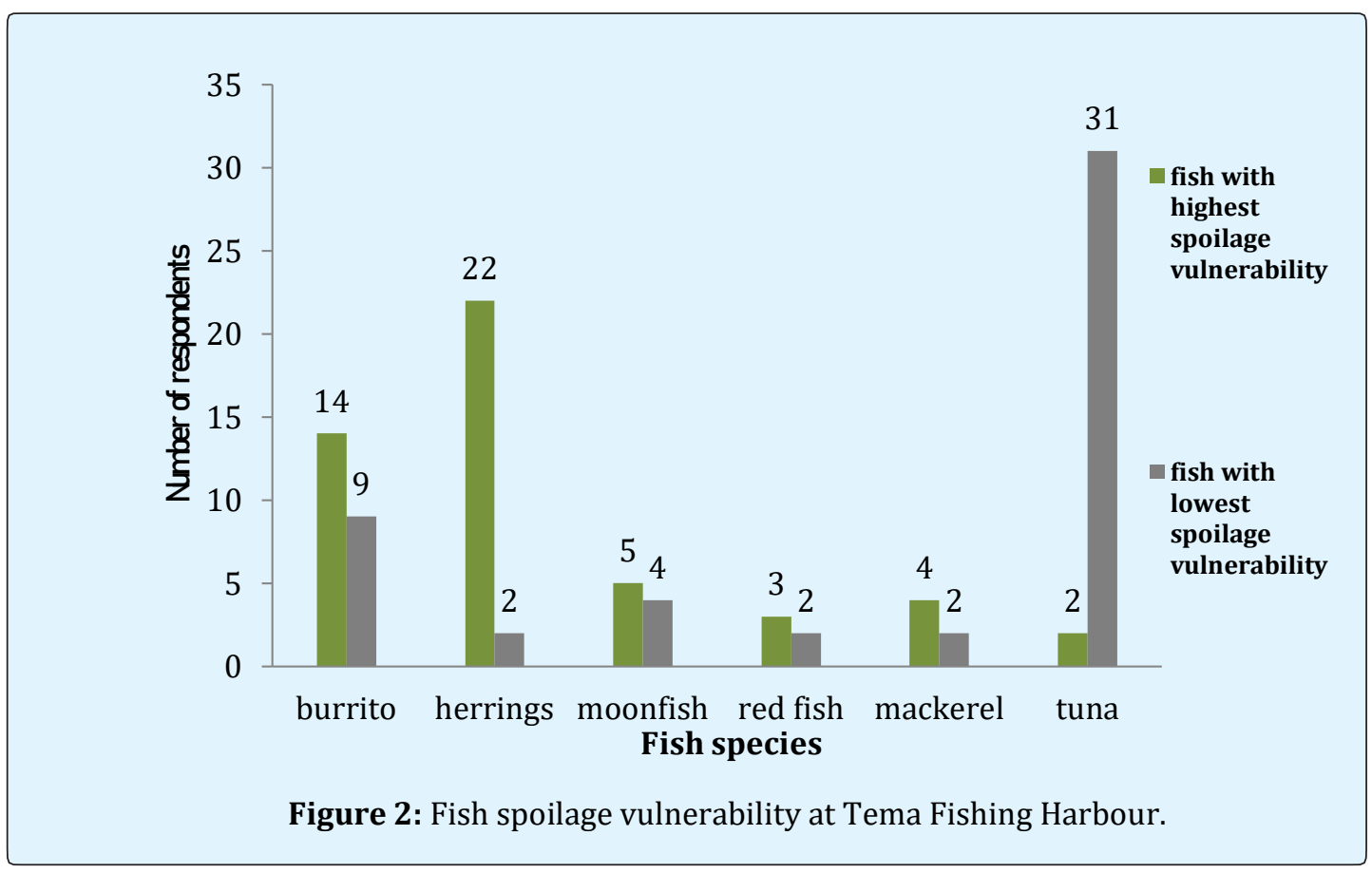

\section{Quantity of Fish Loss}

Fishes harvested at the Tema fishing harbour were measured using crates, with this, three crates were measured and they weighed 10.5, 12.5 and $13 \mathrm{~kg}$ (averagely $12 \mathrm{~kg}$ ). The quantity of fish harvested and bought was given. Out of the 50 fishers, 18 sold and or bought 1-10 crates of fish, 13 sold and or bought 11-25 crates, 9 sold and or bought 26-35 crates, 7 sold and or bought 36-45 crates and 3 of them sold and or bought 4660 crates of fish. It was noted that the number of crates of fish harvested and bought during the period of the study was 1,050 crates amounting to $12,600 \mathrm{~kg}$ (Table 1 ).

\begin{tabular}{|c|c|c|c|c|}
\hline $\begin{array}{c}\text { Number of crates } \\
\text { harvested }\end{array}$ & $\begin{array}{c}\text { Landing site } \\
\text { (fishermen) }\end{array}$ & $\begin{array}{c}\text { Transport destination } \\
\text { (fishmongers) }\end{array}$ & $\begin{array}{c}\text { Number of } \\
\text { fishers(total) }\end{array}$ & Percentages \\
\hline $\mathbf{0 1 - 0 c t}$ & 10 & 8 & 18 & 36 \\
\hline Nov-25 & 7 & 6 & 13 & 26 \\
\hline $\mathbf{2 6 - 3 5}$ & 6 & 3 & 9 & 18 \\
\hline $\mathbf{3 6 - 4 5}$ & 5 & 2 & 7 & 14 \\
\hline $\mathbf{4 5 - 6 0}$ & 2 & 1 & 3 & 6 \\
\hline Total & $\mathbf{3 0}$ & $\mathbf{2 0}$ & $\mathbf{5 0}$ & $\mathbf{1 0 0}$ \\
\hline
\end{tabular}

Table 1: Number of crates harvested and or sold and number of fishers. 


\section{International Journal of Oceanography \& Aquaculture}

The quantity of crates of fish that was lost is given in Table 3. Out of the 50 fishers, 27 lost 1-3 crates of fish per day, 19 lost 4-6 crates and 4 of them lost 7-10 crates. The quantity of fish lost at the landing site and during fish transport is 183 crates, an equivalent of 2,196 kg of fish (Table 2).

\begin{tabular}{|c|c|c|c|c|}
\hline $\begin{array}{c}\text { Quantity of crates of fish } \\
\text { loss }\end{array}$ & $\begin{array}{c}\text { No. of respondents at the } \\
\text { landing site(fishermen) }\end{array}$ & $\begin{array}{c}\text { No. of respondents at the transport } \\
\text { destination(fishmongers) }\end{array}$ & $\begin{array}{c}\text { Total no. of } \\
\text { fishers }\end{array}$ & Percentage \\
\hline $\mathbf{1 - 3}$ & 17 & 10 & 27 & 54 \\
\hline $\mathbf{4 - 6}$ & 10 & 9 & 19 & 38 \\
\hline $\mathbf{7 - 1 0}$ & 3 & 1 & 4 & 8 \\
\hline & $\mathbf{\Sigma} \mathbf{3 0}$ & $\mathbf{\Sigma = 2 0}$ & $\boldsymbol{\Sigma}=\mathbf{5 0}$ & $\boldsymbol{\Sigma}=\mathbf{1 0 0}$ \\
\hline
\end{tabular}

Table 2: Quantity of fish lost and the number of people who lost that quantity.

1, 31 and 18 correspondents agreed that a crate of fish (which could be any of the fish species harvested since the prices differ and were group into ranges) was sold for 100-200, 201-300 and 301-400 (GHC) respectively.
Table 3 shows the money that was to be made during the period of the study. The amount of money that could have been made from the 1050 crates of fish was GHष14,224.5 (2621.79\$), but due to post-harvest fish loss, 183 crates of fish, which could have cost GH 42418.2 (445.77\$) was lost.

\begin{tabular}{|c|c|c|c|c|}
\hline Fishermen & $\begin{array}{c}\text { Transporters } \\
\text { (fishmongers) }\end{array}$ & Total number of fishers & $\begin{array}{c}\text { Amount per crate } \\
\text { (GHC) }\end{array}$ & Mean amount per crate (GHC) \\
\hline $\mathbf{1}$ & 0 & 1 & $100-200$ & 150 \\
\hline $\mathbf{2 0}$ & 11 & 31 & $201-300$ & 7765.5 \\
\hline $\mathbf{9}$ & 9 & 18 & $301-400$ & 6309 \\
\hline $\mathbf{\Sigma} \mathbf{3 0}$ & $\sum=20$ & $\sum=50$ & & $\sum \mathbf{1 4 , 2 2 4 . 5 ( 2 6 2 1 . 7 9 \$ ) .}$ \\
\hline
\end{tabular}

Table 3: The price per crate of fish and the number of people who sold and bought.

\section{Discussion}

Quality loss refers to fish that have undergone changes leading to spoilage or physical damages and there has been deterioration in its quality. It is known to be the most common PHFL in many areas [10]. Physical fish loss can be placed into two distinct ways; firstly complete loss, where quantities of fish are known to be completely spoilt and inedible for humans but they are mostly used for fish meal. Secondly, the one perceived to be material loss, which is because of poor handling and processing of both fresh and cured fishes. It could be as a result of poor handling and preservation or discarding of untargeted species. Physical loss can also be caused by theft, by insects feeding on the fish, or by bird or any animal predation. Rough handling and poor packaging can be associated as a direct cause of physical loss $[10,11]$.

The research revealed that most fishers experienced physical loss (86\%) followed by quality loss (68\%). Physical loss and quality loss are the highest types of post-harvest fish loss experienced in the fisheries sector and they happen due to mishandling, net entanglement, destruction by other fleets and also fish not properly persevered on board $[2,10,11]$.

From the results obtained, the highest and lowest spoilage vulnerabilities (herrings and tuna respectively) recorded during the research could be because of the handling processes undertaken by the fishers as indicated by Huss $\mathrm{HH}$ [12], that rough handling causes faster fish spoilage rate. Furthermore, numerous studies have revealed that herrings have expressively reduced storage life if they are uncovered to sun and wind for some time before icing [13]. Besides, according to Maas-van Berkel B [14], in the high ambient temperatures of the tropics, fish will begin to spoil within 12 hours after harvest and it points out that all the fish species; burrito, herrings, redfish, moonfish, mackerel, and tuna might get spoilt.

The result of this research also showed that $12,600 \mathrm{~kg}$ of fish were landed and or bought during the study period and out of which 2,196 kg were affected by post-harvest fish loss. This loss forms part of the $25 \%$ of gross primary agricultural and fishery products annually [15] and 30\% of landed fish are lost to microbial activities alone [16]. According to the research, the amount of money to be 


\section{International Journal of Oceanography \& Aquaculture}

made by all the 50 respondents (fishers) sums up to GH\&14,224.50 (2621.79\$) out of which GH\&2,418.20 (445.77\$) was lost due to post-harvest fish loss. The research work took three months to complete, which means, within these three months (quarter a year), GH\&2,418.20(445.77\$) was lost due to PHFLs. Averagely, out of 50 fishers, each fisher will lose GH $\$ 48.36$ (\$8.71) for the three months of the study period. Thus approximately, each of these 50 fishers will lose GH\&193.46 (\$34.9) yearly to post-harvest fish loss. If this amount of money is lost per fisher each year, we can tell the amount of money that is lost to post-harvest fish loss by all the fishermen at the landing site and also by the fishmongers. It shows how severe post-harvest fish loss is affecting the country monetarily so therefore, there is a need for PHFLs to be checked in the country.

The research also showed that spoilt fish either were disposed of or salted and dried into what is known as 'momoni' (a local name that is given to salt-fermented fish) to be consumed based on the extent of spoilage of the fish. The 'momoni' is mostly sold at an affordable price as compared to that of the fresh and processed ones.

\section{Conclusion}

From the results, it was concluded that PHFLs was higher at the landing site as compared to that at the Ashaiman market. It can be concluded that $17 \%$, which sums up to GH\&2418.2 (445.77\$) of the quantity of fish harvested and or sold (2196kgs), thus, GH $\$ 14,224.5$ (2621.79\$) was lost due to PHFLS at the study area. The results also indicated that herrings had the highest spoilage vulnerability while tuna, on the other hand, had the lowest spoilage vulnerability.

The causes of the post-harvest fish loss were due to high temperatures, poor handling practices, long-distance and hours fishing, time is taken to offload fish and the distance from the landing site through to the transport destination (Ashaiman market) depending on how iced the fish is. The results of the research also indicated that physical loss (86\%) was mostly experienced; followed by quality loss (68\%), then market force loss $(60 \%)$, and then economic loss (38\%).

It is recommended that illegal and chemical fishing should be checked by MOFAD since it was an issue raised by most of the fishermen that the chemicals used lead to early spoilage of fish. Also, fishers should practice good fish preservation and good handling quality methods, as well as short landing durations. The government should support fishermen with ice block as it supports farmers in the country.

\section{Acknowledgement}

Appreciation goes to the United States Agency for International Development (USAID) for supporting this research through the USAID/UCC small undergraduate research grant (2017/2018). University of Cape Coast, Ghana.

\section{References}

1. Adewolu MA, Adoti AJ (2010) Effect of mixed feeding schedules with varying dietary crude protein levels on the growth and feed utilization of Clarias gariepinus (Burchell, 1822) fingerlings. J fish Aquat sci 5(4): 304-310.

2. Akande G, Diei-Ouadi Y (2010) Post-harvest losses in small-scale fisheries: case studies in five sub-Saharan African countries. FAO Fisheries and Aquaculture Technical Rome, paper. No: 550.

3. Bene C (2011) Policy Brief No. 40. CAADP and Fisheries Policy in Africa: Are we 1aiming for the right reform? Food and Agriculture Organization of the United Nations.

4. Kumolu-Johnson CA, Aladetohun NF, Ndimele PE (2010) The effects of smoking on the nutritional qualities and shelf-life of Clarias gariepinus (BURCHELL 1822). African J Biotechnol 9(1).

5. Yola I, Timothy 0 (2010) Proximate composition and consumer acceptability of African mudfish Clarias gariepinus smoked with two energy sources. Bayero J Pure Appl Sci 5(2).

6. Nowsad A (2010) Post-harvest loss reduction in fisheries in Bangladesh: A way forward to food security. FPMU 5(1): 171-179.

7. Ward AR, Jeffries DJ (2000) A manual for assessing post-harvest fisheries losses. Post Harvest Fisheries Research Programme, Programme Report Number 1.

8. Gram L, Dalgaard P (2002) Fish spoilage bacteriaproblems and solutions. Curr Opin Biotechnol 13(3): 262-266.

9. Gram L, Huss HH (1996) Microbiological spoilage of fish and fish products. Int J Food Microbiol 33(1): 121-137. 


\section{International Journal of Oceanography \& Aquaculture}

10. Diei-Ouadi Y, Mgawe YI (2011) Post-harvest fish loss assessment in small-scale fisheries: a guide for the extension officer. FAO Fish Aquac Tech Pap I.

11. Ames GR (1990) The kinds and levels of post-harvest losses in African inland fisheries. In Proceedings symposium post-harvest fish technology, Cairo, pp: 21-22.

12. Huss HH (1995) Quality and quality changes in fresh fish. FAO Rome, paper 348.

13. Hansen P (1981) Chilling catches in artisanal fisheries. World Fish 30(29).
14. Maas-van Berkel B (2004) Preservation of fish and meat. Agromisa Foundation.

15. Baird-Parker TC (2000) The production of microbiologically safe and stable foods. Microbiol Saf Qual food 1:3-18.

16. Amos B, Sector F, Einarsson H, Eythorsdottir A (2007) Analysis of quality deterioration at critical steps/points in fish handling in Uganda and Iceland and suggestions for improvement. United Nations Univ, Uganda. 